\title{
Influence of an Urban Paved Environment on Tree Dimensions and Vitality Characteristics: A Case Study of Sycamore Maple (Acer pseudoplatanus L.)
}

\author{
Saša Kostić1, Jelena Čukanović², Mirjana Ljubojević², \\ Ksenija Hiel $^{2 *}$, Emina Mladenović \\ ${ }^{1}$ University of Novi Sad, Institute of Lowland Forestry and Environment, Novi Sad, Serbia \\ ${ }^{2}$ University of Novi Sad, Faculty of Agriculture, Department of Fruit Growing, Viticulture, \\ Horticulture and Landscape Architecture, Novi Sad, Serbia
}

Received: 15 June 2018

Accepted: 7 October 2018

\begin{abstract}
In this research, tree sensitivity to the surrounding highly paved environment was analysed at several locations within one urban core (Novi Sad, Serbia). In the future, urban areas will become denser and will, in interaction with intensive climate change, negatively affect the urban forestry performance. Hence, in-depth understanding of the interactions between site-specific parameters, such as pavement and trees, is necessary. When conducting analyses, in this research the data was separated into four groups $(0-2 ; 2-4 ; 4-6 ;>6 \mathrm{~m})$ by two grouped parameters that define the interaction between trees and paved surfaces across the streets. The findings revealed that paved surroundings exerted the most significant effect on tree dimensions and lower on vitality. Moreover, tree height, diameter at breast height, crown width and phytopathological and entomological damage emerged as the most reliable indicators of plant stress caused by the negative influences of a paved environment. Reduced uniformity was noted for trees closer to the traffic and in areas with a narrow landscape strip. In general, the distance from the traffic has a stronger influence than the width of landscape strip on the analysed tree characteristics. Furthermore, the sycamore maple and its red leaf cultivar can be recommended for planting in highly paved areas across streets.
\end{abstract}

Keywords: sycamore maple, urban biotope, paved urban environment, street tree 


\section{Introduction}

Human activities exert significant pressure on ecosystems across the globe. It is estimated that $30-50 \%$ of land area is presently designated for agricultural and urban systems [1]. Plants, especially trees, are major regulators of global and local climate [2, 3]. Thus, they are crucial to the attempts to neutralise climate change [4] and improve air quality in urban areas [5]. On the other hand, changes to local and global climatic conditions affect plant morphology, potentially inducing unfavourable modifications [6]. When current tree biometry is compared to that of two centuries ago, trees have become bigger and weaker due to intensive climate change $[7,8]$.

Highly urbanised areas have an adverse impact on human health [9], the diversity of insects, birds and other animals [1, 10] as well as tree performance [11]. Moreover, air pollution and solar radiation are becoming a significant problem in highly urbanised areas [12, $13]$, affecting not only human health $[14,15]$ but also tree fitness [16]. The selection of tree species is one of the first steps in improving air quality, because the gas exchange is limited by plant stress as well as genetics [17]. Introducing trees into highly paved and urbanised areas can improve bioclimatic comfort for residents, while enhancing other environmental services, such as offsetting carbon emissions, removing air pollutants, regulating the microclimate, and recreation $[18,19]$.

The aforementioned problems regarding pavement and street trees are not new [20]. Along the streets and other highly urbanised areas, trees are typically surrounded by impervious pavement-covered parking lots, roads, and driveways, which increases soil surface and rhizospheric temperature [21], while reducing water infiltration and air gas exchange into the soil [22] as well as nutrient availability [23, 24]. The use of permeable pavement can thus improve tree performance in highly paved surroundings. Moreover, the growing recognition of the need to protect the environment has led to the introduction of non-toxic recycled plastic. These materials are strongly recommended for use in permeable pavement construction, as this would have a positive effect on urban forestry [25-27].

Urban biotope imposes multiple environmental stresses on plants that adversely affect and often modify their function $[28,29]$. Street trees are an integral part of the urban environment, and are the category of urban forestry that is the most exposed to the negative influences caused by highly urbanised areas [13, 28]. Many researchers have noticed different mechanisms and intensities of response and adaptations to stress factors. More precisely, changes were observed in allometric relationships [30], along with the reduction in biomass production, annual growth and vitality $[20,31]$. In addition, highly paved areas indirectly contribute to urban heat islands [32], which then produce osmotic stress [33] and induce changes in plant phenology [34].
Structural and functional elements of streets (i.e., site-specific factors), such as pavement, street geometry, urban furniture, built structures, etc., affect trees [35]. Kostić et al. [36], among other researchers, confirmed the influence of parking lots on tree biometry.

Sycamore maple (Acer pseudoplatanus L.) is the most widely spread maple in European forests [37]. Sycamore maple and its red leaf cultivar (Acer pseudoplatanus 'Atropurpureum' Späth.) are ubiquitous in urban areas with temperate climate across the northern hemisphere (North America, Europe and Asia) [38]. Yang [39] highlighted the fact that sycamore maple is resistant to climate change and should thus be introduced into highly urbanised and significantly changed urban habitats. This species is often planted along streets, because it is highly tolerant to polluted air and soil, and can thrive even in highly urbanised environments [40]. Available evidence suggests that it can be used in highly paved areas since its roots do not degrade pavement structure [41, 42].

The aim of the present study was to investigate the influence of pavement surface area on sycamore maple dimensions and its vitality characteristics when planted along urban streets. Deeper understanding of the interaction between the paved environment and trees will help elucidate the ecosystem services of urban forestry and tree behaviour in highly paved areas, such as streets.

\section{Materials and Methods}

\section{Data and Site Descriptions}

The sample included sycamore maple (Acer pseudoplatanus) and its red leaf cultivar ( $A$. pseudoplatanus 'Atropurpureum') across the streets. (Statistically significant differences between them have not been noticed, hence it is not further interpreted separately in this work.) Analysed trees were arranged in the greenery from two municipalities in Vojvodina Province in the Republic of Serbia: 1) Novi Sad (N45'15'; E19 $50^{\prime}$ ) and 2) Petrovaradin (N45 14'; E19 $52^{\prime}$ ), separated by the Danube river. The analyses included 303 trees, out of which 223 trees are less than $6 \mathrm{~m}$ from the road and up to 205 trees are a noticed width of landscape strip of less than $6 \mathrm{~m}$.

The analysed areas are at an average altitude of from 75.9 to $83.0 \mathrm{~m}$ a.s.1. The climate is temperate continental to modified continental, fully humid with warm summers, according to the Köppen-Geiger climate classification [43]. The main annual temperature and precipitation are $11.2^{\circ} \mathrm{C}$ with an annual range of $22.1^{\circ} \mathrm{C}$ and $603.1 \mathrm{~mm}[44]$.

\section{Data Analysis}

In this work the date was separated into four groups: 1) 0-2 m, 2) 2-4 m, 3) 4-6 m and 4) $>6 \mathrm{~m}$. It is defined 


\section{TYPE 1}

\section{TYPE 2}

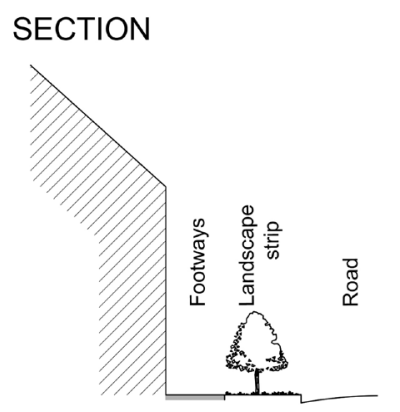

PLAN
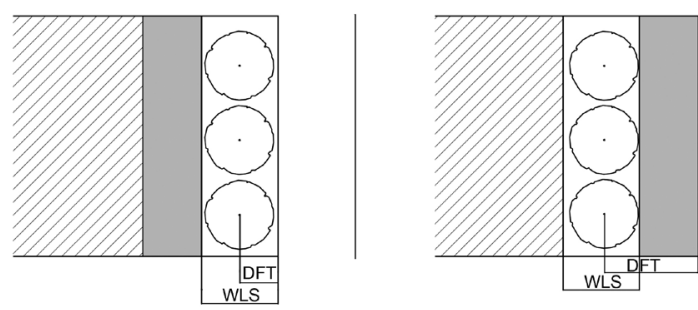

Fig. 1. Two most common types of street arrangement and measured parameters WLS and DFT.

by two grouped parameters (WLS and DFT) separately. Measurement of parameters DFT and WLS into two common street arrangements was presented on Fig. 1. The number of trees and their distributions included in the analysis are shown in Table 1. Statistically significant differences $(p<0.05)$ between basic species and its cultivar have not been noticed and therefore they are not interpreted in this paper.

Tree dimensions were represented by parameters $\mathrm{H}$, $\mathrm{DBH}, \mathrm{CW}$ and HFB and they measured in meters (m) with $1 \mathrm{~mm}$ accuracy. Tree Vitality parameters were presented by parameters TBR, MD, PED, VIT and DEC. Parameters TBR, MD and PED were interpreted by scores ranging from 0 (absent) to 3 (strong). Furthermore, parameters VIT, DEC and FT were scored from 1 (poor) to 5 (excellent), according to the generally accepted methodology of urban forestry evaluation [45], valorised by two persons.

\section{Statistical Methods}

The data were statistically processed using STATISTICA 12.6 (Dell, USA) and SPSS Statistics 23 (IBM, Statgraphics Centurion XVI.I). Descriptive statistics were analysed with mean \pm standard error (mean \pm std.error), standard deviation (std.dev.) and coefficient of variation (CV).

Normal distribution of data was partially given. Hence non-parametric statistical tests (such as Kruskal Wallis Test) were used to analyse the characteristics of populations and to define statistically significant differences between groups defined by DFT and WLS, for $p<0.05$ and $p<0.01$. According to Stevens [46], when the data tend to be normally distributed and the sample
Table 1. Data distribution according to the two analysed factors of distance from traffic (DFT) and width landscape strip (WLS).

\begin{tabular}{|c|c|c|}
\hline & \multicolumn{2}{|c|}{ PARAMETERS } \\
\hline & DFT & WLS \\
\hline GROUP & $\mathrm{N}$ & $\mathrm{N}$ \\
\hline $\mathbf{0}-\mathbf{2} \mathbf{~ m}$ & 135 & 70 \\
\hline $\mathbf{2}-\mathbf{4} \mathbf{~}$ & 18 & 132 \\
\hline $\mathbf{4}-\mathbf{6} \mathbf{~}$ & 52 & 21 \\
\hline TOTAL $\mathbf{0}-\mathbf{6}$ & $\mathbf{2 0 5}$ & $\mathbf{2 2 3}$ \\
\hline$>\mathbf{6} \mathbf{m}$ & 98 & 80 \\
\hline TOTAL ALL & $\mathbf{3 0 3}$ & $\mathbf{3 0 3}$ \\
\hline
\end{tabular}

is large enough, a parametric Duncan's post-hoc test can be used to define homogeneity groups for $\mathrm{p}<0.05$.

\section{Results}

The relationships between the urban environment and its influence on trees were interpreted via two parameters: 1) width landscape strip (WLS) and 2) distance from traffic (DFT), which interpret pavement surface arrangement into street canyons. Table 2 presents the results of descriptive statistics of all 10 analysed parameters, grouped into three categories according to the two grouped parameters (WLS and DFT).

According to the DFT parameter, the average values of the tested parameters show that trees from group 2 had the most favourable values for 7 out of 10 parameters, unlike the trees from groups 1 and 3. Trees from group 2 had the highest values for all analysed tree biometry parameters $(\mathrm{H}, \mathrm{HFB}, \mathrm{DBH}$ and $\mathrm{CW})$. Moreover, the majority of the tested quality parameters were in line with biometry once, too. The tested trees' quality parameters from group 2 had the most favourable results for 4 out of 6 analysed parameters. More precisely, they were the lowest values for TBR and MD parameters and the highest values for VIT and DEC parameters. The different correlations between the tested and grouped parameter was noticed, with parameters PED in negative and FT in positive correlations with DFT.

According to the parameter WLS, the highest degree of variability for the group with the narrowest landscape strip (group 1) was observed with 6 out of 10 analysed parameters (H, HFB, CW, TBR, PED and VIT). According to both parameters, the highest variability has been noticed in group 1, which contains trees closer to the traffic, with 5 out of 10 analysed parameters (DBH, HFB, VIT, DEC and FT). The HFB and VIT parameters had lowest values for group 1 according to both parameters (WLS and DFT).

The results of Duncan's test between tested groups according to both parameters (WLS and DFT) showed a statistically significant difference in the majority of 
Table 2. Descriptive statistics of analysed parameters, with width landscape strip (WLS) and distance from traffic (DFT) as grouping variables; letters in bold indicate statistically significant differences based on Duncan's test $(\mathrm{p}<0.05)$.

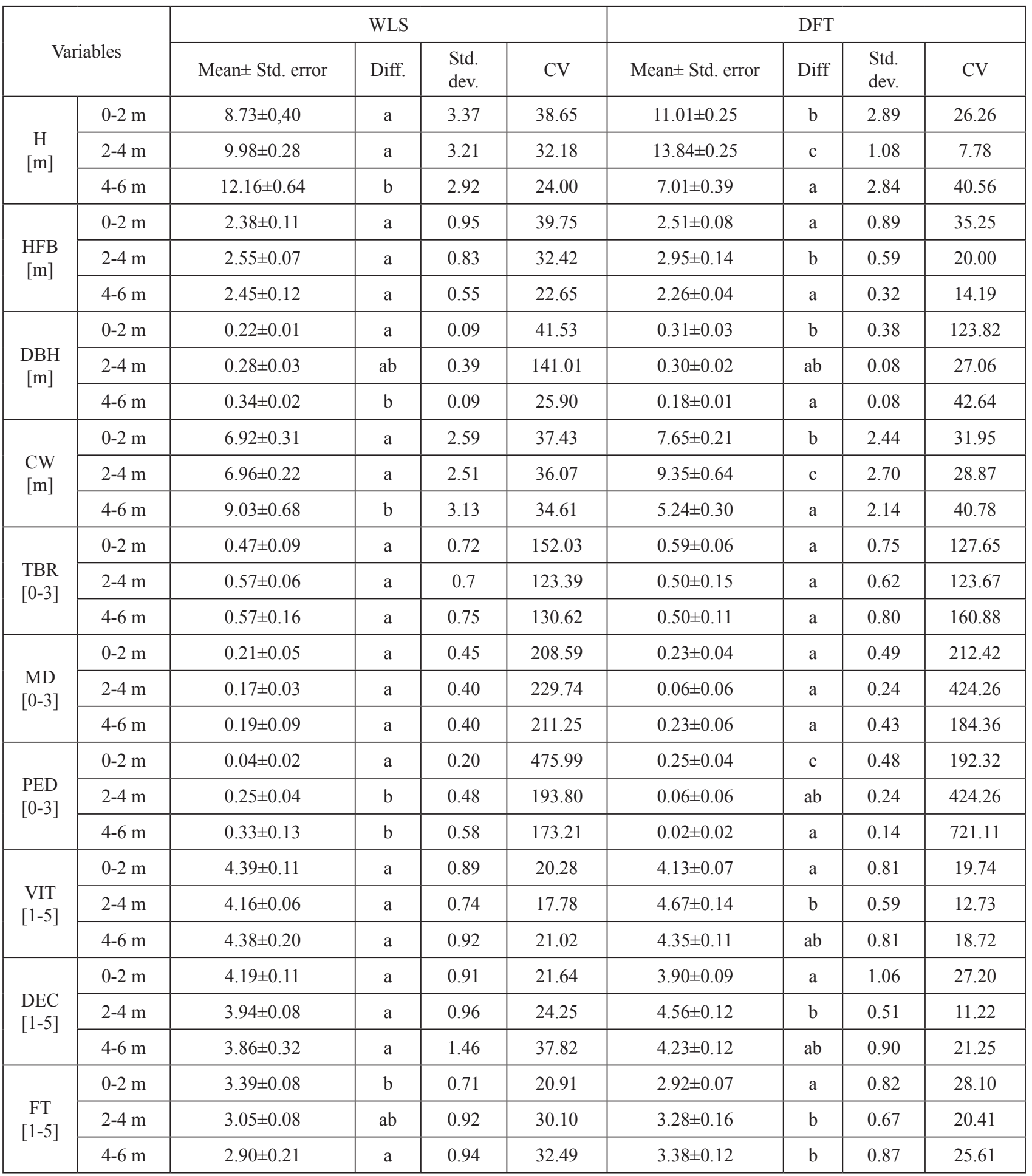

Legend: Height (H); Height to First Branch (HFB); Diameter at Breast Height (DBH); Crown Width (CW); Trunk and Branches Rotten (TBR); Mechanical Damages (MD); Phytopathological and Entomological Damages (PED); Vitality Value (VIT); Decorative Value (DEC), Fruiting (FT).

cases. According to grouping parameter DFT it was noticed to five parameters $(\mathrm{H}, \mathrm{DBH}, \mathrm{CW}, \mathrm{PED}$ and DEC) and according to the second tested grouping parameter (WLS), only in two parameters (DBH and FT). In the largest number of cases it shows a statistically significant difference between two groups ( 1 and 2, as well as groups 1 and 3), with the occasional appearance of a transitional group. The sample of group 3 is small (21 trees) and the data has a robust character, therefore it is a necessarily larger sample to conclude, 
a)

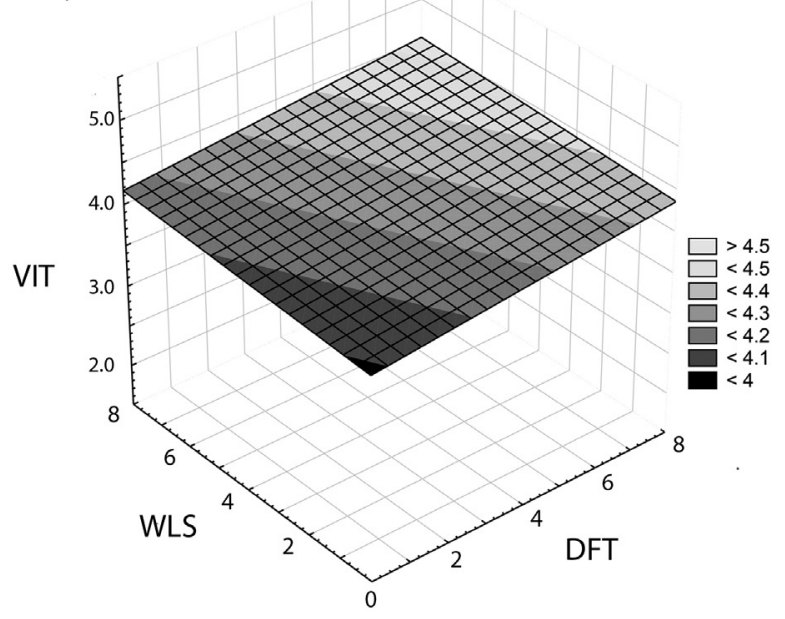

b)

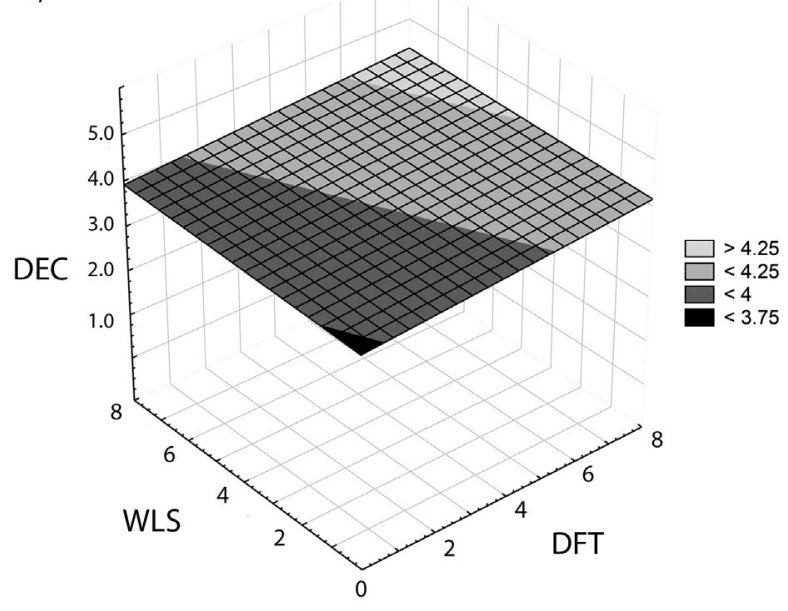

Fig. 2. Linear 3D surface plot diagrams between a) Vitality value $($ VIT $) \times$ Distance from traffic $($ DFT $) \times$ Width landscape strip $($ WLS $)$ and b) DEcorative value $(\mathrm{DEC}) \times$ Distance from traffic $(\mathrm{DFT}) \times$ Width landscape strip $($ WLS $)$, constructed by whole data.

hence in this case obtained results were not reliable and were not interpreted in this work in detail.

The 3D diagrams (Fig. 2) show interactions between three parameters, or more precisely, they represent the influence of both analysed parameters (WLS and DFT) on decorative value (DEC, Fig. 2a) and vitality value (VIT, Fig. 2b). The results indicate that the interaction between DFT and WLS exists, and that they significantly change the VIT and DEC parameters. Trees located on the narrowest width of landscape strip and the smallest distance of street have a low level of vitality and decoration.

The results of the Kruskal-Wallis test with DFT and WLS as grouping variables are shown in Tables 3 and 4. Grouped according to the DFT parameter, statistically significant differences $(p<0.05)$ between groups were observed in parameter DEC, while a highly significant difference $(\mathrm{p}<0.01)$ was observed in seven parameters (H, HFB, DBH, CW, PED, VIT and FT). There was no statistically significant difference for two parameters (TBR and MD). Grouped according to the WLS parameter, a statistically significant difference was observed for one parameter (VIT) and a highly significant statistical difference with four parameters (H, DBH, CW and PED).
With the comparative analysis of the results of the Kruskal-Wallis test, according to DFT and WLS as grouping variables, a statistically significant difference was observed for 4 parameters $(\mathrm{H}, \mathrm{DBH}, \mathrm{CW}$ and PED) while parameters TBR and MD did not have statistically significant differences. Grouped according to the WLS parameter, the highest statistical significant difference and the highest data differentiation of the separated groups were noted for parameter $\mathrm{DBH}$ $\left(x^{2}\right.$ 54.46). In another group, according to DFT parameter, the highest values were observed for parameter $H\left(x^{2}\right.$ 72.57). Significantly high values were also present with parameters $\mathrm{CW}\left(\mathrm{x}^{2} 45.05\right)$ and $\mathrm{DBH}$ ( $\left.x^{2} 39.78\right)$.

\section{Disccusions}

Results in this study established differences in 8 of 10 analysed tree characteristics grouped by both analysed parameters (DFT and WLS), which indicate tree sensitivity to them. On the other hand, to two tested parameters (MD and TBR) differences weren't noticed. The first parameter MD was defined with anthropogenic activity and space arrangement.

Table 3. Kruskal Wallis Test, with distance from traffic (DFT) as grouping variable.

\begin{tabular}{|c|c|c|c|c|c|c|c|c|c|c|}
\hline & $\begin{array}{c}\mathrm{H} \\
{[\mathrm{m}]}\end{array}$ & $\begin{array}{c}\mathrm{HFB} \\
{[\mathrm{m}]}\end{array}$ & $\begin{array}{c}\mathrm{DBH} \\
{[\mathrm{cm}]}\end{array}$ & $\begin{array}{c}\mathrm{CW} \\
{[\mathrm{m}]}\end{array}$ & $\begin{array}{c}\text { TBR } \\
{[0-3]}\end{array}$ & $\begin{array}{c}\text { MD } \\
{[0-3]}\end{array}$ & $\begin{array}{c}\text { PED } \\
{[0-3]}\end{array}$ & $\begin{array}{c}\text { VIT } \\
{[1-5]}\end{array}$ & $\begin{array}{c}\text { DEC } \\
{[1-5]}\end{array}$ & $\begin{array}{c}\text { FT } \\
{[1-5]}\end{array}$ \\
\hline $\mathrm{x}^{2}$ & 72.57 & 19.99 & 39.78 & 45.05 & 1.85 & 3.15 & 14.35 & 12.97 & 10.11 & 27.76 \\
\hline $\mathrm{df}$ & 3 & 3 & 3 & 3 & 3 & 3 & 3 & 3 & 3 & 3 \\
\hline Asymp. Sig. & $0.00^{\mathrm{a}}$ & $0.00^{\mathrm{a}}$ & $0.00^{\mathrm{a}}$ & $0.00^{\mathrm{a}}$ & 0.61 & 0.37 & $0.00^{\mathrm{a}}$ & $0.00^{\mathrm{a}}$ & $0.02^{\mathrm{b}}$ & $0.00^{\mathrm{a}}$ \\
\hline \multicolumn{8}{|c|}{ a. Significant for $\mathrm{p}<0.01 ; \mathrm{b}$. Significant for $\mathrm{p}<0.05$} \\
\hline
\end{tabular}

Legend: Height (H); Height to First Branch (HFB); Diameter at Breast Height (DBH); Crown Width (CW); Trunk and Branches Rotten (TBR); Mechanical Damages (MD); Phytopathological and Entomological Damages (PED); Vitality Value (VIT); Decorative Value (DEC) 
Table 4. Kruskal Wallis Test, with width landscape strip (WLS) as grouping variable.

\begin{tabular}{|c|c|c|c|c|c|c|c|c|c|c|}
\hline & $\begin{array}{c}\mathrm{H} \\
{[\mathrm{m}]}\end{array}$ & $\begin{array}{c}\text { HFB } \\
{[\mathrm{m}]}\end{array}$ & $\begin{array}{c}\text { DBH } \\
{[\mathrm{cm}]}\end{array}$ & $\begin{array}{c}\text { CW } \\
{[\mathrm{m}]}\end{array}$ & $\begin{array}{c}\text { TBR } \\
{[0-3]}\end{array}$ & $\begin{array}{c}\text { MD } \\
{[0-3]}\end{array}$ & $\begin{array}{c}\text { PED } \\
{[0-3]}\end{array}$ & $\begin{array}{c}\text { VIT } \\
{[1-5]}\end{array}$ & $\begin{array}{c}\text { DEC } \\
{[1-5]}\end{array}$ & $\begin{array}{c}\text { FT } \\
{[1-5]}\end{array}$ \\
\hline $\mathrm{x}^{2}$ & 32.50 & 6.49 & 54.46 & 13.49 & 1.80 & 0.46 & 12.98 & 10.27 & 5.69 & 7.42 \\
\hline $\mathrm{df}$ & 3 & 3 & 3 & 3 & 3 & 3 & 3 & 3 & 3 & 3 \\
\hline Asymp. Sig. & $0.00^{\mathrm{a}}$ & 0.09 & $0.00^{\mathrm{a}}$ & $0.00^{\mathrm{a}}$ & 0.62 & 0.93 & $0.01^{\mathrm{a}}$ & $0.02^{\mathrm{b}}$ & 0.13 & 0.06 \\
\hline \multicolumn{8}{|c|}{ a. Significant for $\mathrm{p}<0.01$; b. Significant for $\mathrm{p}<0.05$} \\
\hline
\end{tabular}

Legend: Height (H); Height to First Branch (HFB); Diameter at Breast Height (DBH); Crown Width (CW); Trunk and Branches Rotten (TBR); Mechanical Damages (MD); Phytopathological and Entomological Damages (PED); Vitality Value (VIT); Decorative Value (DEC)

Therefore, its interpretation is not possible on the basis of this experimental design. The results for the second non-significant parameter TBR were uniform and had a small range ( 0.10 unit) of from 0.47 to 0.57 , which may be the reason for the lack of statistically significant differences. Moreover, the values of parameter HFB were defined by the anthropogenic influence, which defines a solitaire tree growth form and explains the uniformity of the data and the insulation of the impact of the urban environment on them.

Grouped according to the parameter WLS, the highest differentiation was noted for parameter $\mathrm{DBH}$, and can be recommended to high sensitivity to tested site-specific parameters. The vitality parameters have the expected distribution and are in line with the distribution of the second grouping parameter (DFT). These results agree with Ferrini and Baietto [47], who showed that the size and type of the non-paved area determines tree health. Furthermore, it was noted that degraded tree health causes early physiological aging of a tree and its dryness [48].

Unlike the previous parameter, the grouping parameter DFT had the strongest influence on tree height and crown width, and less on DBH. This result explains the influence of the paved environment on tree proportion and reduced biomass production, which corresponds to the research of Ramage et al. [49] regarding the relationship of urban area and biomass productions.

Parameter DFT had more influence on tree characteristics than parameter WLS. The smaller influence of parameter WLS on tree characteristics explained the adaptability of sycamore maple to highly paved areas better. Good adaptability was expected due to the tree root architecture. Sycamore maple roots are the largest part in deep soil [42] with larger soil moisture and lower levels of salt and heavy metal concentrations [50]. In this case, root architecture affects the reduction of osmotic and oxidative plant stress, which is reflected in the tree characteristics [48, 51]. Moreover, good adaptability to high paved areas and root damage prevention were caused by root architecture [52]. The results of tree growth parameters $(\mathrm{H}, \mathrm{HFB}, \mathrm{DBH}$ and $\mathrm{CW}$ ) show medium to strong interactions with the analysed parameters of highly paved areas as defined by DFT and WLS, and the parameters of quality characteristics (TBR, MD, PED, VIT, DEC and FT).

This reduced biomass production was a usual plant response to stress factors caused by high urbanity $[11,20,36,43,49]$. Our results are in line with Kostić et al. [36], who researched sycamore maple and its cultivar along with traffic sensitivity to the presence of parking lots. The same results to us were noticed by North et al. [20], who analysed the pavement influence of Norway maple (Acer platanoides L.), which is similar to sycamore maple. Researchers Chen et al. [32] investigated the influence of island heat on common tree species like Manchurian red pine (Pinus tabuliformis Carr.), Chinese ash (Fraxinus chinensis Roxb.) and Shantung maple (Acer truncatum Bunge.) in field experiment that simulated high pavement areas in the streets, and concluded that the pavement raises the ground temperature, which then reduces tree growth, especially DBH, which is in line with our results.

Considering the significantly weak influence of DFT and WLS parameters on the quality characteristics of sycamore maple, we can conclude that this species is justifiably common in the streets of the cities in this and similar climate zones.

In addition, in the group with smaller values (0-2 m), a higher variability of the sample was noted. Starting from the fact that the maple is a highly variable species $[38,41,42,53,54]$, the higher variability within the population expressed through unequal plant responses to urban areas with the same characteristics was expected. On the other hand, the degree of variability was in correlation with the level of urbanity, i.e., higher urbanity caused higher intra-urban variability of urban tree population. This can be constrained by air and soil pollution, heat island and mechanical degradation. They also have an influence on plant physiological processes and have negative effects, particularly on growth characteristics, which are the result of a reduction in biomass production in highly paved areas.

The trees closer to the street had smaller dimensions and degraded tree fitness. The three parameters of tree dimensions $(\mathrm{H}, \mathrm{DBH}$ and $\mathrm{CW}$ ) and one tree vitality parameter (PED) showed a statistically significant difference according to both parameters of urban paved environment (DFT and WLS), and are the most reliable 
for evaluating tree adaptability to stress caused by pavement.

\section{Conclusions}

This study presented trees' sensitivity to paved surfaces. Hence, the tested parameters of distance from traffic and width of the landscape strip adversely affect the quality of urban forestry, and can be include as reliable factors during consideration of urban forestry adaptations to urban habitats. Results in these studies indicate that all tree biometry parameters (tree height, diameter at breast height, crown width) as well as some tree vitality parameters (phytopathological and entomological damage) are the most reliable indicators of plant response to stress factors caused by negative influences of the pavement.

The stress caused by pavement surface on the analysed species and its cultivar has been reflected in the reduction of biomass production and faster appearance of physiological tree aging. These modifications significantly changed quality characteristics and tree fitness, in particular vitality value and decorative value parameters. These characteristics classify sycamore maple into a suitable and highly recommended woody species for further use in highly paved urban areas along streets and other highly urbanised areas.

In conclusion, the findings of our study showed the importance of this and similar research for a better understanding of urban forestry into highly paved areas. Deeper knowledge regarding this topic can contribute to defining interactions between pavement surface and trees and improve their implementation, design of streetscapes and sustainable urban forestry management in the upcoming period of rapidly increasing urbanisation and climate change.

\section{Abbreviations}

Crown Width (CW); Decorative Value (DEC), Diameter at Breast Height (DBH); Distance from Traffic (DFT); Fruiting (FT); Height (H); Height to First Branch (HFB); Mechanical Damages (MD); Phytopathological and Entomological Damages (PED); Trunk and Branches Rotten (TBR); Vitality Value (VIT); Width Landscape Strip (WLS).

\section{Conflict of Interest}

The authors declare no conflict of interest.

\section{Referencess}

1. CONCEPCIÓN E.D., OBRIST M.K., MORETTI M., ALTERMATT F., BAUR B., NOBIS M.P. Impacts of urban sprawl on species richness of plants, butterflies, gastropods and birds: Not only built-up area matters. Urban Ecosyst. 19, 225, 2015.

2. SANUSI R., JOHNSTONE D., MAY P., LIVESLEY S.J. Microclimate benefits that different street tree species provide to sidewalk pedestrians relate to differences in plant area index. Landsc. Urban Plann. 157, 502, 2017.

3. WOLDEGERIMA T., YESHITELA K., LINDLEY S. Ecosystem services assessment of the urban forests of Addis Ababa, Ethiopia. Urban Ecosyst. 20, 683, 2017.

4. MC PHERSON E.G., BERRY A.M., VAN DOORN N.S. Performance testing to identify climate-ready trees. Urban For. Urban Green. 29, 28, 2018.

5. SEVIK H., AHMAIDA E.A., CETIN M. Chapter 31: Change of the air quality in the urban open and green spaces: Kastamonu sample. In Ecology, planning and design, Irina Koleva; Ulku Duman Yuksel; Benaabidate, L., Eds. St. Kliment Ohridski University Press; 409, 2017.

6. CETIN M., SEVIK H., YIGIT N. Climate type-related changes in the leaf micromorphological characters of certain landscape plants. Environ. Monit. Assess. 190, 404, 2018.

7. PRETZSCH H., BIBER P., SCHÜTZE G., KEMMERER J., UHL E. Wood density reduced while wood volume growth accelerated in Central European forests since 1870. For. Ecol. Manag. 429, 589, 2018.

8. PRETZSCH H., BIBER P., SCHÜTZE G., UHL E., RÖTZER T. Forest stand growth dynamics in Central Europe have accelerated since 1870. Nat. Commun. 5, 4967, 2014.

9. ULMER J.M., WOLF K.L., BACKMAN D.R., TRETHEWAY R.L., BLAIN C.J.A., O'NEIL-DUNNE J.P.M., FRANK L.D. Multiple health benefits of urban tree canopy: The mounting evidence for a green prescription. Health Place. 42, 54, 2016.

10. JAMES BARTH, B.; IAN FITZGIBBON, S.; STUART WILSON, R. New urban developments that retain more remnant trees have greater bird diversity. Landsc. Urban Plann. 136, 122, 2015.

11. DAVID A.A.J., BOURA A., LATA J.-C., RANKOVIC A., KRAEPIEL Y., CHARLOT C., BAROT S., ABBADIE L., NGAO J. Street trees in Paris are sensitive to spring and autumn precipitation and recent climate changes. Urban Ecosyst. 21, 133, 2017.

12. GROTE R., SAMSON R., ALONSO R., AMORIM J.H., CARIÑANOS P., CHURKINA G., FARES S., THIEC D.L., NIINEMETS Ü., MIKKELSEN T.N., PAOLETTI E., TIWARY A., CALFAPIETRA C. Functional traits of urban trees: Air pollution mitigation potential. Front. Ecol. Environ. 14, 543, 2016.

13. SALEM M., ALMUZAINI R., KISHAWI Y. The impact of road transport on $\mathrm{CO} 2$ atmospheric concentrations in Gaza city (Palestine), and urban vegetation as a mitigation measure. Pol. J. Environ. Stud. 26, 2175, 2017.

14. TURKYILMAZ A., SEVIK H., CETIN M., SALEH E. Changes in heavy metal accumulation depending on traffic density in some landscape plants. Pol. J. Environ. Stud. 27, 2277, 2018.

15. CETIN M. A change in the amount of $\mathrm{CO} 2$ at the center of the examination halls: Case study of Turkey. Ethno Med. 10, 146, 2016.

16. TURKYILMAZ A., SEVIK H., CETIN M. The use of perennial needles as biomonitors for recently accumulated heavy metals. Landsc. Ecol. Eng. 14, 115, 2018. 
17. CETIN M., SEVIK H. Measuring the impact of selected plants on indoor $\mathrm{CO}_{2}$ concentrations. Pol. J. Environ. Stud. 25, 973, 2016.

18. CETIN M., ADIGUZEL F., KAYA O., SAHAP A. Mapping of bioclimatic comfort for potential planning using gis in Aydin. Environ. Dev. Sustain. 20, 361, 2016.

19. JIM C.Y., CHEN W.Y. Ecosystem services and valuation of urban forests in China. Cities 26, 187, 2009.

20. NORTH E.A., D'AMATO A.W., RUSSELL M.B., JOHNSON G.R. The influence of sidewalk replacement on urban street tree growth. Urban For. Urban Green. 24, 116, 2017.

21. TANG C.-S., SHI B., GAO L., DANIELS J.L., JIANG H.-T., LIU C. Urbanization effect on soil temperature in Nanjing, China. Energ. Buildings. 43, 3090, 2011.

22. BALAKINA J.N., MAKAROVA O.V., BONDARENKO V.V., KOUDSTAAL L.J., ROS E.J., KOOLEN A.J., VAN LOON W.K.P. Simulation of oxygen regime of tree substrates. Urban For. Urban Green. 4, 23, 2005.

23. KRAVKAZ KUSCU I., CETIN M., YIGIT N., SAVACI G., SEVIK H. Relationship between enzyme activity (urease-catalase) and nutrient element in soil use. Pol. J. Environ. Stud. 27, 2107, 2018.

24. ZHAO D., LI F., WANG R., YANG Q., NI H. Effect of soil sealing on the microbial biomass, $\mathrm{n}$ transformation and related enzyme activities at various depths of soils in urban area of Beijing, china. J. Soils Sediments. 12, 519, 2012.

25. CETIN M. Landscape engineering, protecting soil, and runoff storm water. In Advances in landscape architectureenvironmental sciences, InTech-Open Science-Open Minds; 697, 2013.

26. CETIN M. Consideration of permeable pavement in landscape architecture. J. Environ. Prot. Ecol. 16, 385, 2015.

27. CETIN M. Pavement design with porous asphalt. PhD Thesis. 2013

28. MULLANEY J., LUCKE T., TRUEMAN S.J. A review of benefits and challenges in growing street trees in paved urban environments. Landsc. Urban Plann. 134, 157, 2015.

29. SEWELAM N., OSHIMA Y., MITSUDA N., OHMETAKAGI M. A step towards understanding plant responses to multiple environmental stresses: A genome-wide study. Plant Cell Environ. 37, 2024, 2014.

30. PRETZSCH H., BIBER P., UHL E., DAHLHAUSEN J., RÖTZER T., CALDENTEY J., KOIKE T., VAN CON T., CHAVANNE A., SEIFERT T., DU TOIT B., FARNDEN C., PAULEIT S. Crown size and growing space requirement of common tree species in urban centres, parks, and forests. Urban For. Urban Green. 14, 466, 2015.

31. KOSIOREK M., MODRZEWSKA B., WYSZKOWSKI M. Levels of selected trace elements in scots pine (Pinus sylvestris L.), silver birch (Betula pendula L.), and norway maple (Acer platanoides L.) in an urbanized environment. Environ. Monit. Assess. 188, 598, 2016.

32. CHEN Y., WANG X., JIANG B., WEN Z., YANG N., LI L. Tree survival and growth are impacted by increased surface temperature on paved land. Landsc. Urban Plann. 162, 68, 2017.

33. XIONG L., ISHITANI M., ZHU J.K. Interaction of osmotic stress, temperature, and abscisic acid in the regulation of gene expression in Arabidopsis. Plant Physiol. 119, 205, 1999.
34. ZIPPER S.C., SCHATZ J., SINGH A., KUCHARIK C.J., TOWNSEND P.A., LOHEIDE S.P. Urban heat island impacts on plant phenology: Intra-urban variability and response to land cover. Environ. Res. Lett. 11, 054023, 2016.

35. SCHWETS T.-L., BROWN R.D. Form and structure of maple trees in urban environments. Landsc. Urban Plann. 46, 191, 2000.

36. KOSTIĆ S., ČUKANOVIĆ J., LJUBOJEVIĆ M., HIEL K., MLADENOVIĆ E., SENTIĆ I., MRĐEN S. Influence of parking lots on characteristics of street trees, case study sycamore maple (Serbia). In 21 $1^{\text {st }}$ International eco - conference Aleksić N., Ed. Ecological Movement of Novi Sad: Novi Sad, Serbia, 151, 2017.

37. RUSANEN M., MYKING EUFORGEN T. Technical guidelines for genetic conservation and use for sycamore (Acer pseudoplatanus). Institute, I.P.G.R., Ed. Rome, 2013.

38. VUKIĆEVIĆ E. Decorative dendrology. Naučna knjiga, Belgrade, 1987 [In Serbian].

39. YANG J. Assessing the impact of climate change on urban tree species selection: A case study in Philadelphia. J. For. 107, 364, 2009.

40. SJÖMAN H., HIRONS A.D., BASSUK N.L. Urban forest resilience through tree selection-variation in drought tolerance in Acer. Urban For. Urban Green. 14, 858, 2015.

41. CVJETIĆANIN R., BRUJIĆ J., PEROVIĆ M., STUPAR B. Dendrology. University of Belgrade, Faculty of Forestry, Belgrade, 2016

42. JOVANOVIĆ B. Dendrology with basics of phytocenology. Naučna Knjiga, Belgrade, 1971 [In Serbian].

43. KOTTEK M., GRIESER J., BECK C., RUDOLF B., RUBEL F. World map of the Köppen-Geiger climate classification updated. Meteorol. Z. 15, 259, 2006.

44. BAJSANSKI I., STOJAKOVIC V., JOVANOVIC M. Effect of tree location on mitigating parking lot insolation. Comput. Environ Urban Syst. 56, 59, 2016.

45. MATTHECK C., BETHGE K., ERB D. Failure criteria for trees. Journal of Arboriculture 17, 201, 1993.

46. STEVENS J. Intermediate statistics. $2^{\text {nd }}$ ed.; Lawrence Erlbaum Associates Publishers: Mahwah, NJ, US, 1999.

47. FERRINI F., BAIETTO M. Effect of compost-amended backfill and paved surface on leaf parameters and physiology of norway maple (Acer platanoides L.). Arboriculture and Urban Forestry 33, 386, 2007.

48. STIKIĆ R., JOVANOVIĆ Z. Physiology of plant stress. University of Belgrade, Faculty of Agriculture, Belgrade, 2012 [In Serbian].

49. RAMAGE B.S., ROMAN L.A., DUKES J.S., MOODY A. Relationships between urban tree communities and the biomes in which they reside. Appl. Veg. Sci. 16 (8), 2013

50. ČUKANOVIĆ J. Biological and production characteristics of horse chestnut (Aesculus hippocastanum L.) secondary populations. University of Novi Sad, Novi Sad, 2015 [In Serbian, with English abstract].

51. TAIZ L., ZEIGER E. Plant physiology. $5^{\text {th }}$ ed.; Sinauer Associates: Sunderland, MA, 2010

52. EQUIZA M.A., CALVO-POLANCO M., CIRELLI D., SEÑORANS J., WARTENBE M., SAUNDERS C., ZWIAZEK J.J. Long-term impact of road salt $(\mathrm{NaCl})$ on soil and urban trees in Edmonton, Canada. Urban For. Urban Green. 21 16, 2017. 
53. KOSTIĆ S., ČUKANOVIĆ J., LJUBOJEVIĆ M., MLADENOVIĆ E., MRDJAN S., SVILOKOS N. Morphometric characteristics of sycamore maple (Acer pseudoplatanus L.) fruits in Novi Sad urban populations. Bulletin of the Faculty of Forestry 116, 69, 2017.
54. ŠIJAČIĆ-NIKOLIĆ M., OCOKOLJIĆ M., VILOTIĆ D., MILOVANOVIĆ J. The genetic potential of mother trees as a basis for Acer pseudoplatanus 'Atropurpureum' plant production. Arch. Biol. Sci. 63, 145, 2011. 